\title{
Dialogismo y síntoma en Abel de Alexis Moreno
}

\section{Dialogisim and symptom in Abel from Alexis Moreno}

\author{
César Farah Rodríguez \\ Universidad de Chile \\ Facultad de Artes, departamento de Teatro. Santiago, Chile \\ cesarfarah@gmail.com
}

Resumen - El presente artículo tiene como objetivo analizar el texto dramático Abel de Alexis Moreno, presentado en escena en octubre del año 2007. Nuestra lectura se sostiene en dos conceptos, el de "síntoma» marxiano, desarrollado desde las aseveraciones lacanianas y completadas por Slavoj Zizek, idea que sólo se desarrolla en el entramado dialógico de una sociedad; el segundo concepto, como consecuencia del anterior, es el de «dialogismo» en Bajtín. El análisis indaga en la dimensión política y social de la obra, intentando desentrañar los resortes ideológicos, textuales y semióticos que Moreno desarrolla para construir su propuesta estética y dramática.

Palabras claves: Teatro chileno, Abel, Alexis Moreno, síntoma, dialogismo.

Abstract - The current article aims to analyze Abel, a dramatic text written by Alexis Moreno, and first presented on stage in October 2007. Our view is based on two concepts: the Marxian "symptom», generated from Lacanian assertions, and completed by Slavoj Zizek, which is only developed in the dialogic framework of a society; the second concept, which is a consequence of the previous one, is the "dialogism» we find in Bajtin. The analysis investigates the political and social dimension of the play, trying to decipher the ideological, textual and semiotic assumptions that Moreno develops in order to build his own aesthetical and dramatic proposal.

Keywords: Chilean theatre, Abel, Alexis Moreno, symptom, dialogism. 
El siguiente trabajo se propone hacer un análisis de la obra Abel estrenada en octubre del año 2007, de la compañía de teatro La María, cuya dramaturgia pertenece a Alexis Moreno, mientras la dirección de la puesta en escena la comparte con Alexandra Von Hummel.

Nuestro análisis propone la lectura del texto dramático Abel desde dos conceptos fundamentales, primero, el de «síntoma» marxiano, tomado desde la aseveración lacaniana en torno a él y posteriormente desarrollada por Slavoj Zizek, este concepto se adopta como parte del entramado dialógico de una sociedad, del cual surge el segundo concepto: «dialogismo» bajtiniano. Además, la línea investigativa presupone dos aseveraciones de origen marxista: la primera es que la sociedad está dividida en clases, la segunda es que esas clases permanecen en una lucha. Aunque ambas afirmaciones parecen obvias, resultan necesarias por las consecuencias analíticas que contienen; no hay ninguna novedad en ellas, ni siquiera cuando el propio Marx declara estos hechos, puesto que en el siglo XIX, como en todo el resto de la historia de la humanidad, ambas aserciones eran conocidas: las diferencias de clases sociales, el acaparamiento de bienes de algunas sobre otras y el control del poder es algo que está claro en Occidente desde las primeras civilizaciones, simbolizado, eso sí, de otros modos. La agudeza marxiana está en la posibilidad de descifrar una relación interna entre la lucha de clases y el estado de desarrollo de un modo de producción, ligando de esa manera la red simbólica de creencias y valores con las manifestaciones de las actividades materiales. ${ }^{1}$

El texto que intentamos analizar, adquiere un punto de vista estético y político que parece obedecer al intento de generar reacciones sociales; una de las cosas que más llama la atención (y nos gusta) es que lo hace sin la desapasionada lógica «estilo Foucault» de otros directores nacionales, por el contrario, asume las contradicciones y preguntas sin respuesta de su propia propuesta, de ahí que escapa a la mirada posestructuralista, ${ }^{2}$ tan cara a la actividad teatral nacional, al incluir una toma de posición política. Lejos de aquella mirada, Moreno plantea una puesta en escena que no es tan naif como para limitarse a proponer un problema social y retirar toda opinión. El hecho, claro está, es que tampoco será tan vulgar como para convertirla en un panfleto, más bien, requiere un receptor que esté dispuesto (desde el capital cultural que posea) a hacerse cargo de un problema social concreto, buscando una reflexión que pasa por reconstruir los espacios en blanco de la obra (está cargada de ellos) en función de una reflexión crítica al orden social burgués capitalista. Lo interesante de esta crítica es que se hace sin la majadera intención de asepsia taxonómica de otros autores teatrales, en ese sentido, insistimos, escapa a esa posición de pequeño Dios observador del mundo que tanto interesa a otros artistas y que podemos rastrear o "arqueologizar», en uno de sus propios términos, en

\footnotetext{
La aclaración resulta válida, fundamentalmente frente al hecho de la constante discusión, puesta en tensión y, a veces, negación que se hace en ciertos círculos académicos, en torno al hecho mismo de utilizar el concepto «lucha de clases» como válido, en medio de la sociedad neoliberal actual.

2 La vinculación entre posestructuralismo y ausencia de toma de posición política aquí no es absoluta y rígi$\mathrm{da}$, de hecho parece discutible, especialmente en torno a la figura de Derrida; sin embargo, al menos en alguna parte de su desarrollo, el posestructuralismo se tradujo en un potente método para rehuir las problemáticas políticas, si el significado se reduce a un «juego de palabras» a un desplazamiento constante de tropos. ¿Cómo se podría hablar de un significado determinado?, si el discurso «construye» la realidad y todo hablar se refiere al hablar, ¿qué sentido tiene pensar en una interpretación de la realidad, mejor que otra? Por supuesto, la discusión es mucho más amplia que una nota al pie de página e innumerables autores, de alto calibre, han entrado en ella: Derrida, Lyotard, o Habermas, Eagleton y Jameson. Simplemente intentamos aclarar que tenemos conciencia del problemático punto.
} 
Foucault. Valdría hacer notar que lo interesante de ver aquí, no es tanto lo que algunos directores de teatro en Chile dicen, lo que hay que tener en cuenta es precisamente "lo que no dicen». Su propia lógica les prohíbe (tal como a Foucault) juicios generales, universales o trascendentales de tipo político-ético en torno a los fenómenos que abordan, pero ese silencio es, precisamente, el punto de tensión en su obra, es un silencio tan elocuente y evidente, que se transforma en una especie de comentario moral. El mismo Foucault, quizá como respuesta a su propia y silenciosa contradicción, termina entendiendo que toda norma, regla o institución, es una forma de repudiable sumisión, el solo hecho de ser nominado ya es una esclavitud; si Foucault creyera en el anarquismo, bien podría ser un anarquista, pero no cree en él; de ahí ese "pesimismo libertario» que lo caracteriza, término que acuña Terry Eagleton (2006) en La estética como ideología, desde ese punto de vista, los montajes de la compañía La María, en nuestra opinión, escapan a esa homologación.

Aunque formalmente, en particular para su puesta en escena, Moreno utiliza elementos posmodernos, la opinión política e incluso ideológica crece por sobre la superficie formal del trabajo en tablas. En ese sentido, no es una obra posmoderna en absoluto, ni en forma ni en contenido. ${ }^{3}$ Si bien en términos explícitos toma rasgos como la fragmentación de los discursos, el quiebre de la lógica principio-medio-fin (cosa por lo demás vista ya desde las vanguardias, a las que entendemos como un «último grito» de la modernidad) o la no resolución conflictual, incluso la falta de profundización coherente de los personajes, al menos en el sentido del verosímil realista, es decir, sin una construcción histórica clásica ni una mímesis perfecta (supuestamente) con «el mundo real» (sea lo que sea que aquello significara); posee otros elementos centrales, del ámbito discursivo en particular, que permiten ver su alejamiento de la lógica posmoderna. Quizá se trate de un viejo problema de los posestructuralistas (a quienes muchos de nuestros beneméritos artistas siguen, pero sin entenderlos, claro está), a saber, el problema de sostener un discurso, en efecto, posestructuralista, pero que mantenga algún nivel de compromiso... Como dijimos, el asunto ya se ve en Foucault, sin embargo, parece aún más patente en Lyotard y aunque algunas de sus obras pretenden tener un extraordinario compromiso en términos de aceptación (compulsiva) de las otredades, resultan borrosos hasta lo sospechoso, ya no decimos los límites, sino los usos y funciones de conceptos sustanciales como verdad, orden, organización social, e incluso ética; de ese modo, es fácil llegar a la idea de que son los grandes relatos los que devienen en los sistemas totalitarios y brutales del siglo XX, ya sean "democráticos» o «facistas», ni por un momento parece ser capaz de pensar en la ferocidad cruel de los valores anti-ilustrados o de la reificación total de la moral burguesa, funcional al capitalismo tardío, donde la historia es inventada, la argumentación es un juego de naipes y la política una película de Hollywood y donde todo es (y no puede ser otra cosa que) seducción retórica.

\footnotetext{
3 Si bien no todo el trabajo artístico de la posmodernidad puede ser «condenado" por su superficialidad y, por cierto, hay autores que más allá de la forma, proponiendo un contenido específico y fundamental en su trabajo artístico (y quizá el caso de Abel es uno de ellos), resulta más o menos de aceptación general que dentro de las particularidades de la posmodernidad, en especial en su veta artística, sobresalen algunas características como la fragmentación, superficialidad, el pastiche como forma modélica, la ambigüedad, la incapacidad de explicarse a sí mismo y el populismo estético, que de seguro provienen del desvanecimiento de la frontera modernista entre cultura de élite o alta cultura y cultura comercial y de masas. De hecho, un autor como Fredric Jameson asevera que el rasgo formalista de la posmodernidad es, justamente, la superficialidad. Para mayor profundización en este punto, se puede consultar su extraordinaria obra Teoría de la posmodernidad (1996).
} 
Desde otro lugar, muy diferente, Moreno articula Abel y eso es lo que intentaremos demostrar en el siguiente texto. Podemos afirmar que la obra de Moreno es en esencia «Dialógica», tomando este concepto desde su sentido bajtiniano; como se sabe, es esta una noción amplia y densa en los escritos de Bajtín, sustentada en un orden de pensamiento antropológico-filosófico, que razona sobre la constitución del ser humano como tal, a través de su discursividad, vista ésta como modo sustancial de las personas para concretizarse como tales. El dialogismo Bajtiniano es un modo de relación humano de carácter fundamentalmente verbal, a través del cual los hombres son capaces de generar semiosis, por tanto, de dotar de sentido al mundo, entendiendo al individuo mismo que lleva a cabo dicho proceso, como parte del mundo semiotizado.

En ese sentido, podríamos decir que la obra Abel está cruzada por completo del concepto de "dialogismo», como si éste fuera una matriz de sentido sustancial al texto de Moreno. La obra propone la necesidad de una discusión social, diríamos que, en particular, dentro del ámbito de la ideología (como modo de aproximación a la realidad), de la política contingente (en clave crítica sobre la situación del ciudadano común en el capitalismo neoliberal) y de la estética (por el modo de exponer la problemática y la apuesta por una obra artística con bases ideológico-políticas). Los personajes que aparecen en escena, tocan, cruzan y reúnen estas fronteras conceptuales, proponiendo una tensión necesaria, así como una discusión y reflexión obligada a un receptor-espectador que tome en serio el espectáculo teatral. El matrimonio burgués: Mujer y Hombre, la Secretaria, el Profesor y la Nana, personajes de la obra, en gran parte de sus textos, manifiestan dicha inquietud. Prueba de ello, son parlamentos constantes, que tocan y mezclan los temas mencionados. Un ejemplo es cómo la obra desde el comienzo tensiona el orden burgués, clase media, continuando con esa demolición desde distintos puntos de vista y haciéndose cargo de lo que podríamos llamar una discusión social valórica.

HOMBRE: Tú nunca me harías algo así.

MUJER: Ah... ¿piensas que lo hice por ti?

Y para tu información pienso seguir haciéndolo.

Ser puta es más digno que haberme convertido en la esposa de un fracasado [...]

HOMBRE: No, señor yo no tengo la culpa de nada.

MUJER: Antes tenía futuro pero me fijé en ti... Podría haber llegado lejos.

HOMBRE: Sí, lejos... Ni siquiera para pasarle la lengua a los sobres te contratarían. Lejos, sí claro... súper lejos ibas a llegar.

MUJER: ¿Ahora nos vamos a humillar?

¿Y qué va a venir después?

¿Te vas a reír de mí con tus amigos?

HOMBRE: Siempre me he reído de ti con mis amigos.

MUJER: Sí, eso podría ser cierto.

HOMBRE: Claro que es cierto.

MUJER: Sí, sería cierto si tuvieras algún amigo (Moreno, 2007: 169-71).

No hay que olvidar que una de las ideas centrales del «dialogismo» es que todo enunciado remite, de algún modo, a toda la cadena de enunciados relacionados a una misma esfera de la praxis humana, tanto los precedentes como posteriores; en ese sentido, la problemática abordada en esta obra, configura la discusión del matrimonio burgués, desde un lugar que no es sólo subjetivo y autorreferencial del autor, sino que conlleva las esferas culturales anteriormente señaladas. 
Lo mismo ocurre con los otros personajes, ellos se constituyen como personajes en tanto su discurso los relaciona, necesariamente, no sólo con los otros elementos de la obra, sino también con los elementos de la sociedad en que el montaje es mostrado; este punto es de capital importancia, no sólo para entender que la obra de Moreno contiene problematizaciones de carácter ideológico, político y estético, sino que permite entender por qué los personajes exigen una completación por parte del espectador y por qué también anuncia que sean un «síntoma» en el sentido que Zizek lo propone.

«La comprensión del signo es el proceso de relacionar un signo dado que tiene que ser comprendido con otros signos ya conocidos, en otras palabras, la comprensión responde al signo con otros signos» (Voloshinov, Bajtin, 1992: 34-6). Declara Voloshinov, además, en torno a esta aseveración, podemos completar diciendo que «El supuesto es que las propiedades de los signos son ideológicas, nadie habla en términos de significados de diccionario, sino en términos de valores, que dan sentido al discurso» (Arán, 2006: 86). Por lo tanto, resulta lógico pensar que cuando hablamos de signos, hablamos también de valores culturales, que se mueven y confrontan en el ámbito de la sociedad y su cultura, política, ideológica y estéticamente, respondiendo, discutiendo, generando semiosis y haciéndose cargo de las diferentes motivaciones que los hacen emerger.

Parece entonces evidente que toda obra artística es dialógica, sin embargo, algunas de ellas lo son más que otras, en tanto hay una clara conciencia dialógica en su construcción.

Por otra parte, si bien Bajtín le da preponderancia dentro de los géneros discursivos a la novela, como la que con mayor fuerza contiene el dialogismo en su modo de ser, el teatro nos parece un lugar extraordinariamente dialógico y la obra de Moreno resulta notable en ese sentido. La estructura de la obra Abel es heterogénea y compleja, discordante, paradójica a veces, cosa que parece particularmente evidente en el discurso de sus personajes, el texto está plagado de ese tipo construcciones, llega a parecer innecesario citarlas, a modo de ejemplo, sólo algunas:

La ex secretaria: [...] Me van a despedir, ¿sabe? Y yo soy una buena empleada, ejemplar... Me gusta mi trabajo... Ahora no sé qué voy a hacer... Yo soy una muy buena trabajadora, una vez obtuve como premio un tazón de muy buena calidad... Sí, para el café de las doce... Siempre bebía un café a las doce. Pero ya no más. A las doce no voy a tener nada que hacer, el café no tendrá el mismo sabor... Estaré desempleada, qué vergüenza, Dios mío. Necesito hablar con alguien...

La verdad es que no tengo trabajo hace meses.

La verdad es que no puedo hablar con nadie (Moreno, 2007: 186).

En otro momento, con una carga más emotiva y social:

La ex secretaria: [...] Entramos y los vimos a todos.

Hirviendo, literalmente.

Usted miraba la catástrofe mientras yo retenía su olor.

Con esos ojos miraba.

O se muere tranquilo o asustado, pensé.

El destino del obrero siempre está predestinado, pensé.

Los sacaron al otro día, hinchados, completamente cocidos. Fue imposible reconocerlos.

Mañana, cuando los saquen, un niño idiota en alguna esquina se reirá.

Mañana, cuando las esposas vieron a sus maridos cocidos y un niño idiota reía en la esquina yo sabré que usted también murió.

Me gustaría ser ignorante.

Porque la ignorancia es un dolor desconocido (189). 
El profesor tampoco escapa a esta categorización:

[...] Un alumno estúpido me preguntó alguna vez dónde estaba el alma...

Yo sólo sé del sistema nervioso.

Yo...

Aceptar es mi único atavío mamífero. Porque el valor no es más que un cobarde que de improviso se ha vuelto loco.

Como Segismundo soy un animal grosero, sucio, un asesino, un condenado.

En el gran Teatro del mundo...

Todo es postizo para nosotros, personajes que no comprenden los artificios...

Acepto mi pesadilla (mi nombre es Segismundo, el prisionero), asumo el rigor de la muerte, esta inquietud esotérica. ¡Ay, mísero de mí! ¡Ay, infelice! Apurar, cielos, pretendo, ya que me tratáis así... ¿¿Qué delito cometí contra vosotros, naciendo?! Aunque si nací, ya entiendo qué delito he cometido: Bastante causa ha tenido vuestra justicia y rigor, pues el delito mayor del hombre, es haber nacido... (Moreno, 2007: 192).

Resultan más o menos claras, más allá de los pequeños ejemplos aquí citados y si se sigue la obra completa, dos cosas fundamentales. Primero, que el lenguaje aquí no sólo es un medio de mimesis, sino que es también un objeto representado, las características formales emergen también («también», no únicamente) como un modo de comunicación, hay un extrañamiento del lenguaje cotidiano que busca remover la relación «normal» del receptor con el lenguaje, la relación de «utilidad», para volcarla a una experiencia estética reflexiva, en segundo término y como consecuencia de lo anterior, se derriba la idea de una verdad unitaria, completa y absoluta, de una verdad final posible de mantener estática y siempre igual a sí misma, al exponer la intensa y compleja vida del lenguaje en el seno de lo social, se demuestra que la única forma de exponer la realidad, es exponer al lenguaje como generador de verdades.

Pero ¿qué es, finalmente, lo que en concreto se pone en perspectiva dialógica en la obra de Moreno? El siguiente punto que proponemos como sostén de la obra Abel y como línea de análisis responde a ello: es la mostración que hace el autor, a través del dialogismo del texto, de la fractura y sinrazón del sistema capitalista, el quiebre de la racionalidad de la sociedad, en la obra de Moreno los dispositivos sociales del capitalismo tardío están vistos desde un punto de vista políticamente crítico y centrados en el interior de los modos de producción; lo que afirmamos, es que los personajes de la obra son el «síntoma» marxiano, propuesto por Lacan, tema que Slavoj Zizek desarrolla en una parte de su texto El sublime objeto de la ideología.

Según Zizek, quien completa la reflexión lacaniana, Marx descubre una falla, un quiebre en el orden trascendental de la organización valórica de derechos y deberes de la burguesía. Lo crítico aquí, pasa por entender que esta grieta no es una imperfección que, según avance la civilización capitalista, vaya a corregirse, sino que es un rasgo constituyente. Tal como lo expone Zizek: «el «síntoma〉 es, hablando estrictamente, un elemento particular que subvierte su propio fundamento universal, una especie que subvierte su propio género» (2003: 47), de ahí la paradoja que se produce, pues en cada libertad universal está contenido el caso específico que rompe su verdad, el círculo siempre debe cerrarse con el opuesto del universal. El obrero que vende de forma libre su trabajo al capitalismo, es justo allí donde pierde esa libertad, es el punto de excepción que niega internamente el valor de libertad capitalista, en tanto Marx ensaya una sociedad donde exista el intercambio de mercancías, con una producción de mercado fuerte, pero donde los obreros continúen estando en poder de los sistemas de producción, pretende una sociedad sin el «síntoma» del capitalismo. 
Vista la organización social como racional, articulada como completa, aparece así, un elemento interno, que al mismo tiempo de constituir dicha organización, fractura el principio universal racional del sistema completo; en Marx, ese elemento es el proletariado, el punto de quiebre en que una sociedad racional choca contra la irracionalidad, generada por sí misma. Desde ese punto de vista, al representar a caracteres que se encuentran precisamente en esa paradoja, podemos decir que los personajes de la obra Abel son, más que sintomáticos, un síntoma. Este tema aparece en el discurso de los personajes al momento de presentar el conflicto mismo de la obra, pues en Abel, el conflicto genera a los personajes, como funciones de la acción dramática, esos personajes son lo que son, sólo en tanto el conflicto dramático en el que se ven envueltos. ${ }^{4}$ Los personajes pertenecen a la baja burguesía o al proletariado; la obra comienza, primero con la imposibilidad de comunicación entre ellos:

MUJER: ¡Quédate acá! No me dejes hablando sola. Conversemos.

HOMBRE: No quiero conversar.

MUJER: Ah, no quieres conversar.

HOMBRE: No, no quiero conversar, contigo nunca se puede hablar de nada (Moreno, 2007: 165).

Falta de comunicación que luego devendrá en la transformación de los personajes, en signo de su propio conflicto dramático. El conflicto dramático se suele definir como el choque de dos fuerzas antagónicas que intentan someterse la una a la otra, las fuerzas opositoras en Abel, generadoras de conflicto, no están fuera de los personajes, sino en ellos mismos, provienen del sistema social en el que se hallan, pero ellos mismos son parte constituyente de ese sistema y, al mismo tiempo, la paradoja contradictoria del mismo. El conflicto se genera en torno al problema del desempleo, en tanto los personajes pierden su trabajo, pierden dignidad, humanidad, espacio de respeto y existencia en el sistema. El sujeto del sistema capitalista, tiene lugar en él, en tanto produce y consume, si no puede llevar a cabo estas actividades, queda marginado del sistema, se convierte en un paria, una vergüenza, situación que ilustra la obra en varios momentos, cuando Mujer le pre-

\footnotetext{
4 Efectivamente, se podría argüir frente a esta aseveración que todo personaje de una obra dramática, es ese personaje en relación a la acción que en ella se desarrolla, está envuelto en ella y vive dicha acción como una forma integrante de su propio carácter, cosa en la que estamos en completo acuerdo. Sin embargo, creemos que hay niveles de determinación en torno al tema que son significativos en la creación del mundo dramático de cada obra en particular. Por ejemplo, hay personajes que son tomados de un acervo cultural específico y que tienen «vida propia» fuera de las obras, por ejemplo Edipo o Agamenón, quienes pertenecen a la historia nacional (mítica si se quiere) de Grecia, por lo tanto tienen existencia en otros ámbitos culturales de la comunidad, lo que les da ciertas características específicas que deberían repetirse cada vez que dichos personajes son expuestos; por ejemplo, la soberbia de Agamenón es parte de su carácter, pero que ya sea que esté representado en Iliada o en La orestiada aparecerá igual. Esto también ocurre con obras más modernas, el caso de Prat de Manuela Infante, donde el personaje central, pertenece a la historia nacional de Chile. Resulta notorio como, personaje y obra, generaron un escándalo mayúsculo en el país, precisamente porque el «Arturo Prat» al interior de la ficción teatral, no tenía relación con el verosímil mítico-histórico de la cultura chilena.

En ese sentido, resulta interesante notar que los personajes de la obra Abel tienen un alto grado de indeterminación, sus nombres no son propios, sino genéricos: Hombre, Mujer, Secretaria, Profesor, Nana, respondiendo a un tipo social (una marca brechtiana, seguramente); no conocemos nada de su historia anterior, sólo tenemos lo que sucede en la obra y aun en ella, la indeterminación es importante: ¿cuál es la fábrica, o de qué, donde trabaja Hombre?, ¿en qué tipo de colegio hizo clases Profesor?, son preguntas que permanecen abiertas, creemos, en función de lograr una generalidad que permita reconocer a los personajes de la obra como genéricos de una sociedad y donde ellos como individualidad no crezcan en importancia, por sobre el tema tratado y su discurso.
} 
gunta a Hombre en la primera escena, por qué no le ha contado que fue despedido del trabajo, la sintomática respuesta de este es "porque me daba vergüenza» (Moreno, 2007: 174), en el capitalismo, el trabajo «da dignidad» no por una valoración óntica del mismo, sino porque genera recursos, produce la posibilidad de consumir, como ya anotamos, al quedar fuera del círculo dialéctico de producción y consumo, el hombre deja de ser ciudadano e incluso humano, para ser un despojo; más adelante en la obra, el discurso extremiza esta situación:

HOMBRE: ¡Y yo estoy desesperado! Me convirtieron en un inútil. Si a un hombre le quitan su trabajo le cortan los brazos, le pudren su mano de obra, se va la dignidad, la civilización... ¡¿De qué sirvo si no trabajo?! ¡iMe vuelvo loco porque estoy aburrido, porque me desechan y no tengo las fuerzas para aguantar la vergüenza!! (Moreno, 2007: 175).

Sin embargo, resulta interesante que los valores del hombre de esta escena continúan siendo los valores burgueses: se niega a aceptar que su mujer es infiel, o que se comporte como prostituta (nunca queda del todo claro en la obra si esto ocurre realmente o no), tampoco ha querido contarle que ha perdido el empleo, «un hombre no puede ponerse a llorar delante de su mujer», dirá, intentando exponer las motivos de su mentira; el hecho es que el personaje es justamente el síntoma marxiano en tanto manifiesta los valores burgueses y constituye un modo de simbolización del mundo burgués, con valores de tal corte, pero es, precisamente, la fractura, la rajadura del sistema mismo la que, por lo demás, lo ha creado, tanto como burgués y como quiebre.

La segunda escena de la obra concibe con igual precisión la pendiente del desempleado como personaje síntoma. Una vez más, la obra comienza con la idea de la comunicación truncada, con la imposibilidad lógica de la comunicación, el personaje central (y único) de esta escena es una secretaria que está llamando por teléfono incesantemente, haciéndose pasar por empleada de la compañía de teléfonos, sólo con el afán de conversar con alguien al otro lado de la línea.

El personaje de la «Secretaria» caracteriza la misma problemática anterior al mostrar la ausencia de dignidad del sujeto al perder el trabajo. La idea de «Trabajo» deviene así como punto nodal ${ }^{5}$ de la construcción semiótica del sujeto en tanto ser humano, pero como ya mencionamos antes, esta constitución es doblemente problemática, primero por no generarse como un valor ético y, segundo, por fundar la paradoja del síntoma que niega la universalidad de los postulados de la sociedad burguesa.

Dice la secretaria, casi al comenzar su monólogo que sólo un par de líneas más adelante continúa con la aceptación de que no puede hablar con nadie, la aceptación de la desvinculación social, a propósito de su desempleo. En este sentido, el personaje va avanzando por una curva que implica su desintegración, de hecho, lo que vemos en escena, es el proceso de desintegración del personaje en cuanto sujeto participante de la red

\footnotetext{
Entendemos aquí, «punto nodal» en el sentido en que Zizek lo elabora, en El sublime objeto de la ideología, donde dice: «El cúmulo de ssignificantes flotantes», de elementos protoideológicos, se estructura en un campo unificado mediante la intervención de un determinado <punto nodal, el point de caption>lacaniano, que los 〈acolcha〉, detiene su deslizamiento y fija su significado» (Zizek, 2003: 125), más allá de la discusión posterior de desde dónde proviene este acolchamiento del punto nodal, nos interesa el concepto, como instrumento de comprensión de cómo cada uno de los elementos de un campo ideológico determinado, formando parte de una serie de equivalencias, se relaciona con los otros elementos, determinando retroactivamente su identidad, pero para que dicho encadenamiento sea posible, es necesario el punto nodal, englobando sus elementos y generando la identidad de campo.
} 
simbólica, para observar cómo deviene en aquella grieta del orden capitalista, síntoma paradójico.

La ex secretaria: [...] Nuestro trabajo es lo único que tenemos y se lo agradecemos.

Nuestro trabajo era lo único que teníamos y usted nos lo quitó.

Ojalá algún día se arrepienta.

¿Quién soy?

Yo es otra (Moreno, 2007: 186).

Dice instantes después, exponiendo el proceso de pérdida de trabajo evidenciado en las dos primeras líneas; posteriormente está la pregunta por la identidad, ésta se desplaza ("yo es otra») por un cualquiera, el personaje es un "síntoma», el desplazamiento obedece a la imposibilidad de mantener "una» identidad porque el personaje es cualquiera de la comunidad, es un funtivo al interior del mundo presentado, es, en tanto funtivo de este mundo, un "síntoma» marxiano. En este sentido, lo importante de ver, es que el personaje está en un proceso de desintegración de la personalidad, en camino a una especie de catatonia (recordemos que en muchos casos, el último estadio de avance de la esquizofrenia, es precisamente, la catatonia del paciente), por la imposibilidad de comunicarse, pero este avance a la locura, no se trata simplemente del golpe emocional sufrido por el personaje, no es sencillamente la ilustración emotiva de una mujer sola y embarazada, ¿qué diferencia tendría esto con una teleserie chilena, mexicana o venezolana?

Como el trabajo dramatúrgico de Moreno no intenta surfear la superficie de la cultura y no es un pastiche posmoderno en desesperada búsqueda de un populismo estético, sino por el contrario, parece un angustiado trabajo ético-político, lo que está en juego aquí, en esa descomposición de la personalidad de la Secretaria, es que ella deja de ser sujeto y tiende a enloquecer porque es marginada del tejido simbólico y empujada al núcleo duro y traumático de lo no ideológico que muestra la realidad tal como es, un lugar al que no se puede acceder sino en una especie de locura iluminadora; en ese sentido, los cuerdos estarían «locos», precisamente por estar en el entramado simbólico y actuar como si eso fuera la realidad y los atisbos de locura de la secretaria no serían otra cosa que su enfrentamiento con ese espacio de realidad «total» que, en nuestra opinión, se concretizan en el hijo que lleva en sus entrañas.

La aceptación de y participación en el orden simbólico siempre se materializa en nuestra actividad social, la Secretaria no es un personaje exagerado y sobredimensionado, patemizado al extremo que pierde su cordura por el dolor pasional que el mundo le ha provocado, ella es un síntoma. La realidad social es una construcción ética que nos permite actuar como si el mundo efectivamente significara lo que pretendemos, como si la democracia fuera efectivamente la posibilidad de la participación de todas las voces, como si el presidente de la república representara la voluntad de Chile, justamente, cuando la Secretaria se enfrenta al hecho concreto de que nada de esto es así, de que existe un núcleo traumático, un "porque sí», atisba la realidad "tal como es», sin simbolizar, eso la acerca a la lucidez total, que es la locura para el orden simbólico. Es del carácter absurdo del sistema de donde se desprende que debamos «funcionar en él», su autoridad simbólica proviene de su propio acto de enunciación, la Secretaria es como Alicia que cruza al otro lado del espejo. La suposición de una verdad radical, de un orden último detrás del sistema ético y valórico, sólo es funcional para quienes creen en él.

Es, exactamente, como en la escena final de La broma asesina, un libro-comic de Batman, escrito por Alan Moore y dibujado por Brian Bolland; al final de la historia y después de una cruenta lucha, Batman y el Guasón se quedan solos, en las afueras de 
un campo de juegos abandonado. Batman habla con honestidad al Guasón y le ofrece ayuda, si seguimos en esto, le dice el hombre murciélago a su archienemigo, nunca terminaremos, al menos hasta que uno de los dos muera; por qué no sigues un tratamiento, por qué no intentamos, ambos, honestamente ayudarte y sacarte de tu locura, expone el caballero enmascarado.

No podría, responde el Guasón; te explicaré por qué, dice, y le cuenta el siguiente chiste: hay dos locos en un manicomio, que planean escapar, el modo será el siguiente: el manicomio está separado por un muro a gran altura de otro edificio, si logran cruzar, estarán libres; esa noche deciden hacerlo, llevan una linterna, uno se queda en el manicomio, enciende la linterna y el primer loco cruza el abismo caminando por sobre el haz de luz, el otro le arroja la linterna al que ya cruzó, éste la enciende y le dice a su compañero, vamos, cruza ya; pero el que aún está en el manicomio, duda y finalmente le dice: no, no lo haré. ¿Por qué?, pregunta el otro. Estás loco, responde el que se queda; ¿y si después, a mitad de camino, me gastas una broma y me apagas la linterna?

Por supuesto, esto debe entenderse, no como que la vida es sólo una fantasía, una realidad virtual estilo The Matrix, sino que hay un núcleo duro, irreductible a sí mismo y resistente a la simbolización, la «verdad» es aquello que nunca cesa de no decirse y por tanto (sólo por tanto) se genera el entramado simbólico.

De hecho, no hay que olvidar que la Secretaria está preñada, preñada de un hijo que, según podemos concluir, pertenece a su jefe, que es también un asesino y una especie de violador. Ese hijo que lleva en su vientre, es parte de ese núcleo duro de realidad, irreductible sino a sí mismo, situación que ella caracteriza del siguiente modo:

La ex secretaria: [...] Que mi voz no se le olvide porque de seguro no se acuerda de mi rostro, ¿verdad? Porque cuando me tocaba yo estaba ahí, contra la pared.

Porque cuando me viole tampoco se dará el trabajo de mirarme a la cara, le bastará con una amenaza de despido...

Eran tiempos difíciles, donde una mujer honrada tenía que degradarse en su propio trabajo para poder asistir regularmente a un supermercado.

Mire mi estómago.

¿No siente el olor?

Estoy esperando que el niño nazca para matarlo yo misma. Reventarlo en el capó de su auto.

Olor a quemado (188).

El vientre lleno de ese hijo de olor a quemado, es un fragmento de lo real, una manifestación de ese "otro" que no puede ser integrado a la red simbólica, un constituyente de la secretaria que es toda la secretaria, es lo que la está haciendo enloquecer, pero al mismo tiempo, es lo que la mantiene viva y congruente.

Resulta, en todo caso, interesante pensar que no hay en la obra una mirada romántica o nihilista que proponga la negación total de la civilización, tampoco la destrucción total del mundo, sino más bien, lo que hay en el texto es el cuestionamiento profundo del sistema, precisamente desde una actitud ética; sólo estando dentro de un sistema de coordenadas éticas es posible una crítica tan radical, sin devenir en la obscenidad del fascismo.

Los personajes de Abel se encuentran fetichizados por lo que podemos llamar el desplazamiento de la fetichización de la mercancía; este deslizamiento, justamente se relaciona con el síntoma, porque, de acuerdo con Zizek, Marx desarrolla su concepto de síntoma, en el paso del feudalismo al capitalismo; en resumen, la idea es que el lugar del fetichismo (en el paso del feudalismo al capitalismo) se ha desplazado de esfera, de estar 
entre las relaciones intersubjetivas a las relaciones entre cosas, las relaciones interpersonales de dominio y esclavitud ya no se muestran directamente, en el sentido del señor y sus esclavos, sino que se "disfrazan» (luego, nunca desaparecen), en la forma de relaciones entre productos. Así, las relaciones de dominio y esclavitud se reprimen en términos formales, como anota de modo magistral Zizek, con el surgimiento de la sociedad burguesa, generando el «síntoma» histérico (Zizek, 2003: 53).

En ese sentido, el Profesor que deviene en Segismundo en Abel, enfoca con precisión el «síntoma» del falso reconocimiento fetichista. Zizek recoge una afirmación lacaniana de que un loco que cree que es rey no está más loco que un rey que cree que lo es, es decir, un rey que supone que la cualidad simbólica de «Rey» está en él mismo per se y no por el cúmulo de relaciones simbólico-sociales en el que interactúa. La lectura que hace el Profesor de Abel de Segismundo es precisamente esa, de ahí la necesidad de desgarrar el texto de Calderón y poner al personaje de Segismundo como un loco idiota y patético que pretende ser Rey, que cree en su «imperialidad» como un rasgo de su naturaleza propia, simplemente por el hecho de ser «Rey»; este proceso se genera de manera ambigua, a través de lo que podríamos llamar una especularización de discursos donde se confunden los discursos del Profesor como personaje, en tanto reflexiones de su propia historia, en una suerte de soliloquio (acordemos que éste es un mónologo) de Segismundo, personaje de La vida es sueño, y también incluyendo el monólogo de la empleada; esta última, recordemos, en escena, es representada por el mismo actor que hace de Profesor y habla de sí misma en tercera persona, de algún modo es "hablada» por esta mezcla de caracteres, como concreción sintomática final de la reificación capitalista, donde más allá de la personalidad de cada sujeto, se trata de una red de relaciones sociales de intercambio de mercancías, poniendo al «rey Segismundo», al Profesor y a la Empleada, en un punto de cruce que los convierte en uno solo, precisamente por su cesantía, devenida en exclusión social.

La Empleada dice:

[...] Este ha sido un día extraño, la empleada lo sabe. Sus patrones discuten peligrosamente, ella ya sabe por qué, la empleada aterrada no quiere ser despedida, no puede volver desechada a su país. Se puede quedar por menos, ¿me puedo quedar por menos dinero, señora?

La empleada querrá creer que todo fue una confusión, que lo que oye es parte del programa que se emite por el aparato, que la discusión no es más que una escena declamada sordamente por los personajes pintorescos del programa que se emite por el aparato.

La empleada no quiere aceptar ser el daño colateral de la situación de sus patrones (Moreno, 2007: 193).

Dice el Profesor, en su primer texto de escena:

Segismundo estuvo preso toda su vida, hasta que lo liberaron en un teatro abarrotado de gente, lo despertaron, lo depositaron en una escenografía barata para que todos se burlaran de él (Moreno, 2007: 191).

Constituyendo así la perversión de La vida es sueño, la liberación de Segismundo aquí, pasa por su ingreso a la red simbólica, que permite la constitución del personaje de Calderón en un símbolo, nunca completo, de esta representación ideológica que más arriba mencionamos. El problema está en la comprensión de esto por parte del Profesor, al tener él esta conciencia, como personaje de Abel y al mismo tiempo, estar degradado al extremo, precisamente por haber perdido su trabajo, el Profesor advierte que él ha sido un loco absurdo e idiota, como Segismundo. Y dice entonces: «Segismundo no pudo 
vivir en su texto, ni en un mundo real, porque, al igual que yo, sólo era una criatura que la educaron en el rigor del absurdo, uno de tantos que fue comprimido» (192). Llama la atención, además, que dice «en «un〉 mundo real» manifestándose allí la posibilidad de más de un mundo, la eventualidad de más de un orden simbólico, lejos de la realidad unívoca, absoluta y controlada del empirismo, una red simbólica cuyos signos-valores están en constante lucha, en permanente efervescencia cultural, en fin, en continuo "dialogismo».

En última instancia, tal como la Secretaria comienza a desintegrarse al final de su recorrido monológico, el mundo presentado por Moreno, en la escena cuarta (y última) se desmorona, se aniquila. En esta última escena, el personaje central es el más marginado de todos, sus marcas son ser mujer, extranjera y pobre, todos sellos que la ponen en el borde del entramado simbólico de la sociedad. Las marcas de la aniquilación de este mundo se manifiestan en su inconexión discursiva, en la imposibilidad de ese cosmos simbólico por constituirse congruentemente, desde el orden gramatical normalizado. La marca de enrarecimiento del mundo, se da a través de los modos gramaticales, en particular las discordancias de tiempos y personas verbales como indicadores de un aniquilamiento fundamental, pero ¿por qué?, seguramente, porque la obra está, implacablemente, restregándonos en la cara nuestro error como sujetos receptores de la obra. No hay que olvidarlo, es una obra política: el error está en pretender que ese mundo tiene un rol en sí mismo, un secreto que se nos develará en una revelación final de la obra, pero el secreto ya está en la obra misma y en nosotros como receptores de ella; es un llamado ético a la reflexión política, ideológica y estética que, necesariamente, en forma dialógica, debiéramos completar.

\section{REFERENCIAS}

Arán, Pampa (Comp). (2006). Nuevo diccionario de la teoría de Mijaíl Bajtín. Córdoba: Ferreyra editores.

Eagleton Ferry. (2006). La estética como ideología. Trad. de Germán Cano y Jorge Cano. Madrid: Trotta.

Jameson, Frederic. (1996). Teoría de la posmodernidad. Madrid: Terra.

Moreno, Alexis. (2007). Abel. En Ramón Griffero (editor), Dramaturgia chilena contemporánea: siete autores. Santiago: Universidad Arcis.

Voloshinov, V. y Mijaíl Bajtín. (1992). El marxismo y la filosofía del lenguaje. Trad. de Tatiana Bubnova. Madrid: Alianza.

Zizek, Slavoj. (2005). El sublime objeto de la ideología. Trad. de Isabel Vericat. Buenos Aires: Siglo XXI.

Recepción: marzo, 2008

Aceptación: julio, 2008 